\title{
Functional Outcome of Surgery for Glioma Directly Adjacent to Pyramidal Tract Depicted by Diffusion-Tensor Based Fiber Tracking
}

\author{
Difüzyon Tensör Temelli Fiber İleme Yoluyla Piramidal Traktus \\ Komşuluğundaki Gliom için Cerrabinin Isslevsel Sonucu
}

\author{
Hou YUANZHENG ${ }^{1}, \mathrm{Ma} \mathrm{LICHAO}^{2}$, Chen XIAOLEI ${ }^{1}, \mathrm{Xu} \mathrm{BAINAN}^{1}$ \\ ${ }_{1}^{1}$ LLA General Hospital, Department of Neurosurgery, Beijing, China \\ ${ }^{2} P L A$ General Hospital, Department of Geriatric Endocrinology, Beijing, China
}

Corresponding Author: Xu BAINAN / E-mail: imribook@126.com

\begin{abstract}
AIM: To investigate the outcome of glioma resection surgery and changes of pyramidal tract (PT) for patients where PT is immediately adjacent to the tumors, which were revealed by diffusion tensor imaging (DTI) based fiber tracking (FT) technique.

MATERIAL and METHODS: 40 patients enrolled. Preoperative and intraoperative tractography of the PT was performed before and after glioma resection. Motor function was recorded before surgery and 1 week, three to six months after surgery. Distances (D) between intraoperative tractography of the PT and the resection cavity were measured.

RESULTS: 14 patients had transient aggravated or newly motor deficits 1 week after surgery. After 3 to 6 months follow up, only 3 (7.5\%) patients had permanent deficits. In 12 (30\%) patients, the intraoperative PT tractogram adjoined the resection cavity after tumor removal $(D=0)$. They all had transient aggravated motor deficits after surgery and 3 were permanent. In 19 patients with preoperative motor deficits, 11 $(57.90 \%)$ had zero D value. In other 21 patients, $1(4.76 \%)$ had zero $D$ value. There was significant difference between these two ratio $(p<0.01)$. CONCLUSION: DTI based FT is helpful in protection for the PT during glioma surgery, even if the PT is directly adjacent to the glioma. Patients with preoperative motor deficits faced more risk of persistent aggravated deficits after surgery.
\end{abstract}

KEYWORDS: Fiber tracking, Pyramidal tract, Glioma

öz

AMAÇ: Difüzyon tensör görüntüleme (DTI) temelli fiber izleme (FT) tekniğiyle tümör komşuluğunda piramidal traktus (PT) bulunduğu durumlarda gliom rezeksiyon cerrahisinin sonucunu ve piramidal traktus değişikliklerini incelemek.

YÖNTEM ve GEREÇLER: Çalışmaya 40 hasta kaydedilmiştir. Gliom rezeksiyonundan önce ve sonra PT için preoperatif ve intraoperatif traktografi yapılmıştır. Cerrahiden önce ve cerrahiden 1 hafta ve üç ve altı ay sonra motor işlev kaydedilmiştir. PT intraoperatif traktografisi ile rezeksiyon kavitesi arasındaki mesafeler (D) ölçülmüştür.

BULGULAR: Cerrahiden 1 hafta sonra 14 hastada geçici şiddetlenmiş veya yeni motor defisitler ortaya çıkmıştır. 3 ila 6 ay takipten sonra hastaların sadece 3 'ünde $(\% 7,5)$ kalıcı defisitler görülmüştür. On iki (\%30) hastada tümör çıkarılmasından sonra intraoperatif PT traktogramı rezeksiyon kavitesinin yanında görülmüştür $(D=0)$. Bunların tümünde cerrahiden sonra şiddetlenmiş motor defisitler görülmüş ve $3^{\prime}$ ü kalıcı olmuştur. Preoperatif motor defisitli 19 hastanın 11 'inde $(\% 57,90)$ D değeri sıfır olmuştur. Diğer 21 hasta içinde 1 hastanın $(\% 4,76)$ D değeri sıfır olmuştur. Bu iki oran arasındaki fark istatistiksel olarak anlamlı bulunmuştur $(\mathrm{p}<0,01)$.

SONUÇ: Gliom cerrahisi sırasında PT, glioma hemen komşu olsa bile PT'nin korunması için DTI temelli FT faydalıdır. Preoperatif motor defisitleri olan hastalar cerrahiden sonra uzun süreli şiddetlenmiş defisit açısından daha fazla risk yaşamıştır.

ANAHTAR SÖZCÜKLER: Fiber izleme, Piramidal traktus, Gliom

\section{INTRODUCTION}

Glioma surgery is complicated by maximizing the extent of resection while preserving adjacent white matter tracts, for example, pyramidal tract (PT). PT damage can result in motor deficits in the contra lateral side. The only method, so far, to visualize white matter tracts in vivo is diffusion tensor image (DTI)-based fiber tracking (FT) $(1,11,14)$. Few major brain white-matter tracts including PT can be localized during surgery by integrating the DTI-FT results into standard neuronavigation system $(3,4,7,15,16,22)$. Further, DTIFT can be performed during surgery using intraoperative magnetic resonance imaging (MRI) $(15,22)$; this allows the neurosurgeon to establish the course of white matter tracts at the time of surgery. 
Preliminary studies on brain surgery assisted by the PT navigation have been reported $(3,4,7,15,16,22)$. The outcomes of these series were generally encouraging. But two questions are not quite clear. Firstly, the relationship between the PTs and tumors was not detailed in these reports. In the illustrated cases, some tractogram of PT was directly adjacent to the tumors, while some others were at a short distance from the tumors. So, it was not clear whether PT is more likely to be damaged during surgery and has different functional outcome in the former situation. Logically, this kind of cases is more suitable to verify the accuracy of PT navigation. Secondly, most studies did not employ intraoperative MR. The status of PT during surgery were not mentioned. This made it hard to explain why the patients had different function outcome after surgery, even if the relationship between the PTs and tumors were same.

Hence in present study, we consecutively collected the patients with tractogram of PT was immediately adjacent to the tumors and investigated their surgical outcome. We further investigated the PTs' status by intraoperative DTI based FT and tried to find out the factors leading to different functional outcome.

\section{MATERIAL and METHODS}

\section{Patient Population}

The subjects were collected from the patients who received brain tumor resection surgery assisted by high-field intraoperative MRI combined with PT navigation in our hospital. These patients received MRI scans and tractogram of PT was constructed days before surgery. We consecutively enrolled the patients with glioma whose preoperative tractogram of PT was directly adjacent to the tumors (Figure 1B). The patients with hemiplegic before surgery were excluded. In the end, 40 patients were enrolled. Intraoperative MRI was approved by the local Ethical Committee. Signed informed consent was provided by each patient or by appropriate family members before surgery.

\section{MRI and Data Processing}

MRI scans were performed using a 1.5 Tesla scanner (Siemens Espree, Erlangen, Germany). The DTI data was acquired with single-shot spin-echo diffusion-weighted echo-planar sequence (TE 147 ms, TR 9400 ms, matrix size $128 \times 128$, FOV $251 \times 251 \mathrm{~mm}$, slice thickness $3 \mathrm{~mm}$ ). The diffusion-weighting (high b value) was $1000 \mathrm{~s} / \mathrm{mm}^{2} .12$ gradient directions were obtained. The voxel size was $1.9 \times 1.9 \times 3 \mathrm{~mm}$. Applying five averages; the total DTI measurement required $10 \mathrm{~min}$. The anatomic images were obtained by T1WI 3D MPRAGE sequence (TE $3.02 \mathrm{~ms}$, TR $1650 \mathrm{~ms}$, matrix size $256 \times 256$, FOV $250 \times 250 \mathrm{~mm}$, slice thickness $1 \mathrm{~mm}$ ). Intraoperative DT imaging was performed using the same SS-EPI sequence after tumor removal. Further T1WI MPRAGE scanning was also performed to record changes of brain tissue. All data were transferred to the planning software (iPlan 2.6, BrainLab, Feldkirchen, Germany) for processing. DTI data was directly imported into the iPlan. FA and tensor map were calculated automatically. Anatomic datasets were converted and exported to iPlan using PatXfer 5.2 (BrainLab, Feldkirchen, Germany). These sequences were co-registered by a semiautomatic rigid registration algorithm for further processing.

\section{Fiber Tracking}

FT was implemented in the 'fiber tracking' module of iPlan, which is based on a tensor deflection algorithm (12). We set the FA threshold to 0.15 , minimum fiber length to $50 \mathrm{~mm}$, the angulation threshold to $30^{\circ}$ and step size to $1 / 3$ voxel size before performing fiber tracking $(2,3,9,10,19,21)$. Tract seeding was performed by defining rectangular volumes of interest (VOI) in the coregistered FA map or standard anatomic datasets. We used a two VOI approach, which had been described in our previous paper (7). First, the precentral gyrus was located by anatomical landmarks and confirmed by fMRI, if the fMRI was feasible (6). Then, the first VOI was positioned immediately below the precentral gyrus. Computer allowed tracking of all the fibers projecting from the primary motor cortex. The second VOI was stationed at the cerebral peduncle. The final tracts of interest passing through both VOls were obtained after further exclude the contaminated fibers; a 3D object was then generated by wrapping all the streamlines with a close hull (Figure 1C). This 3D object was interpolated and coregistered with a high-resolution 3D anatomical dataset. This allowed clear depiction of the contour of the PT in each slice (Figure 1B). Each PT was reconstructed by the third author (XLC), who was blind to the patients' syndromes.

\section{Relationship between PT Tractogram and the Tumor or the Resection Cavity}

We browsed all the slices to examine the relationship between PT tractogram and the glioma. The situation where the PT was directly adjacent to the tumor mass was defined as that the contour of PT was tangential to the tumor border (Figure 1B), that is, the distance between the tractogram of PT and tumor was zero. The distance (D) between intraoperative tractogram of PT and the resection cavity was also measured in the same slices by using the 'view' module of the iPlan.

\section{PT Navigation During Surgery}

All data was transferred into the navigation system (VectorVision sky, Brainlab, Feldkirchen, Germany) to guide surgery. The navigation was also connected to the surgical microscope (OPMI Pentero, Carl Zeiss, Germany). All the navigation information could also be shown under the microscope by using lines with different colors (Figure 1D). During the tumor resection, intraoperative MRI scans and FT were performed at least once to learn the extent of tumor resection and the change of PT's location during surgery (Figure 1E, F). If necessary, navigation data was revised with the intraoperative data to guide the further tumor resection.

\section{Motor Function Assessment}

All the patients were examined both preoperatively and postoperatively by an experienced neurologist blind to the patients' case history and neuroimaging results. Postoperative 
examinations were performed at 1 week, and 3, 6 and 12 months after surgery. If the patient could not come to the hospital for reexamination, telephone interviews would be made. The best functional states during this period were recorded. In this process, hand and limb muscle strengths were regard as the major criteria to assess the motor function, which were classified according to the Medical Research Council Scale of 0 to 5 (6).

\section{Statistical Analysis}

The independent samples t-test and Fisher's exact test were adopted for comparison between groups. Statistical analysis was used SPSS 11.0 (SPSS Inc. Chicago, USA). The threshold for statistical significance was set at $\mathrm{P}=0.01$.

\section{RESULTS}

Data of 40 patients (27 male, 13 female; mean age $40.4 \pm$ $15.2 \mathrm{yr}$ ) with glioma were enrolled for analysis. At admission, mild or moderate motor deficits (Muscle Strength Grade 23) were observed in 19 patients. In 20 cases, the locations of the tumors were rolandic or surrounding; 8 tumors in basal ganglions, and 12 tumors in insular lobes. The mean calculated volume was $49.84 \mathrm{~cm}^{3}$ (SD \pm 31.16 , median 42.74 $\mathrm{cm}^{3}$, min $3.35 \mathrm{~cm}^{3}$, max $128.3 \mathrm{~cm}^{3}$ ). 9 patients had low-grade glioma (oligodendroglioma or astrocytoma), 31 patients had high-grade glioma (anaplastic oligodendroglioma, anaplastic astrocytoma, glioblastoma).

Total resections were achieved in 27 (67\%) patients. In other 13 patients, subtotal resections of the tumors were performed because the tumors were much diffused. In these patients, the strategy of intentionally leaving part tumor tissue around PT for the preservation of function was not utilized.

Of the 40 patients, there were no changes or improvement in motor deficits following surgery in $24(60 \%)$ and aggravated or newly motor deficits in 14 patients (40\%) one week after surgery. Only $3(7.5 \%)$ patients had permanent aggravated deficits, but could live independently (KPS score 60-70) after 3 to 12 months follow up. The distance between the tumor mass resection cavity and the intraoperative tractographic localization of PT, the $D$ value, ranged from 0 to $25.8 \mathrm{~mm}$ (mean $6.83 \mathrm{~mm} ; \mathrm{SD} \pm 6.34 \mathrm{~mm}$ ). In 12 of the 40 patients $(30 \%)$ the intraoperative tractogram of PT still adjoined the resection cavity.

All the 12 patients, whose intraoperative tractogram of PT still bordered the resection cavity, had transient aggravated or new motor deficits 1 week following surgeries. 3 of them had permanent aggravated motor deficits 6 to 12 mo after surgeries.

For the patients who had motor deficits before surgery, 11 of $19(57.90 \%)$ had zero D value. While in the 21 patients without motor deficits before surgery, 1 (4.76\%) patient had zero $D$ value. Fisher's exact test showed there was significant difference between these two ratio $(p<0.01)$.
In the 9 patients with low grade glioma, D values were not significantly different from those in other patients $(P>0.1)$ with high-grade gliomas.

\section{ILLUSTRATIVE CASES}

\section{Case 1}

A 14-year-old female suffered from weakness in left extremities (Muscle Strength Grade 4). Preoperative images revealed a space-occupying lesion with ring-like enhancement in the right basal ganglia. Preoperative DTI-Tractography showed that PT was directly adjacent to the posterior edge of the tumor (Figure 1A, B). After tumor removal, intraoperative tractography depicted that PT was $7.5 \mathrm{~mm}$ away from the resection cavity (Figure 1E,F). The patient had aggravated motor deficits one week after surgery (Muscle Strength Grade 3) and recovered to grade 4 six months later. The reexamination images were shown (Figure $1 \mathrm{G}, \mathrm{H}$ ). It was worth noting that the PT was closer to the resection cavity compared with intraoperative images (Figure 1E, F), because of atrophy of brain tissues between them. The pathological result was anaplastic astrocytoma (WHO grade III).

\section{Case 2}

A 45-year-old female suffered from headache but without motor deficiency. Preoperative images revealed a spaceoccupying lesion with obvious enhancement in the right insular lobe. Preoperative DTI-Tractography showed that PT was directly adjacent to the left edge of the tumor (Figure 2A, B). After tumor removal, intraoperative tractography depicted that PT was $11.2 \mathrm{~mm}$ away from the resection cavity (Figure $2 C, D)$. The patient recovered well after surgery without any new motor deficits. The pathological result was astrocytoma (WHO grade III).

\section{Case 3}

A 75-year-old male suffered from headache and mild asthenia in left upper extremities (Muscle Strength Grade 4). Preoperative images showed a space-occupying lesion with ring-like enhancement in the right insular lobe. Preoperative Tractography indicated that PT was directly adjacent to the left border of the tumor (Figure 3A, B). After tumor removal, intraoperative Tractography revealed that PT still adjoined the resection cavity (Figure 3C,D). The patient had left hemiplegia (Muscle Strength Grade 1) after surgery and recovered to grade 3 five months later. The pathological result was glioblastoma (WHO grade IV).

\section{Case 4}

A 36-year-old female suffered from headache and mild asthenia in left extremities (Muscle Strength Grade 4) before surgery. Preoperative images revealed a space-occupying lesion in the right insular lobe. Preoperative DTI-Tractography showed that PT was directly adjacent to the tumor (Figure 4B). After tumor removal, intraoperative Tractography depicted that the distance between PT and resection cavity increased (Figure 4D). The patient recovered well after surgery without 
any new motor deficits. In reexamination MRI of 6 months (Figure 4F), distance between PT Tractography and resection cavity did not change, although the brain tissues shift to normal position compared intraoperative images. The pathological result was astrocytoma (WHO grade II).

\section{DISCUSSION}

In this paper, 40 patients whose tractogram of PT was directly adjacent to the glioma received resection surgeries assisted by high-field intraoperative MRI and PT navigation. The experience with similar system had been reported by Nimsky et al. (15), who got a $6.25 \%$ rate of permanent motor deficits. Similarly, we got $40 \%$ transient aggravated motor deficits and $7.5 \%$ permanent motor deficits. In other reports, the rate of long-term motor deficits ranged from 0 to $15 \%(5,4,7,15,16$, 22). So, our functional outcome was still acceptable compared with the literature data, even if PT was directly adjacent to the glioma. On the other hand, as a generally accepted effective
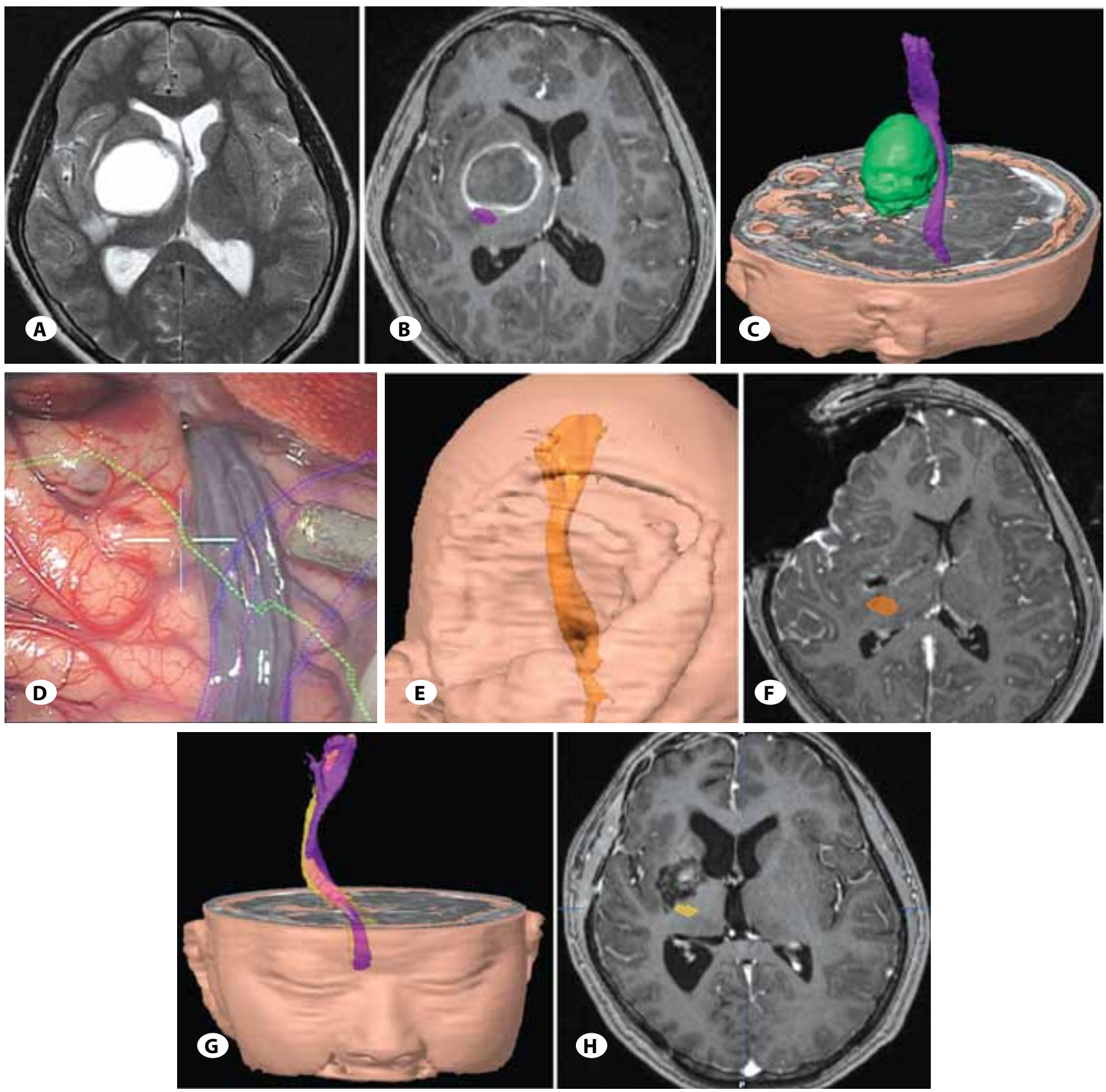

Figure 1: Case No. 1 A, B) Preoperative images. Purple color represents the location of pyramidal tract (PT). C) 3D representation of PT (purple bar) and tumor (green objects). D) Scenes under microscope. Green lines indicate tumor border. Purple lines indicate PT's boundary. E) Intraoperative tractogram of PT (Orange bar). F) Tumor was removed. Orange color indicates PT. G, H) images of 6 months; yellow color indicates PT, which was compared with the preoperative PT (purple color). 

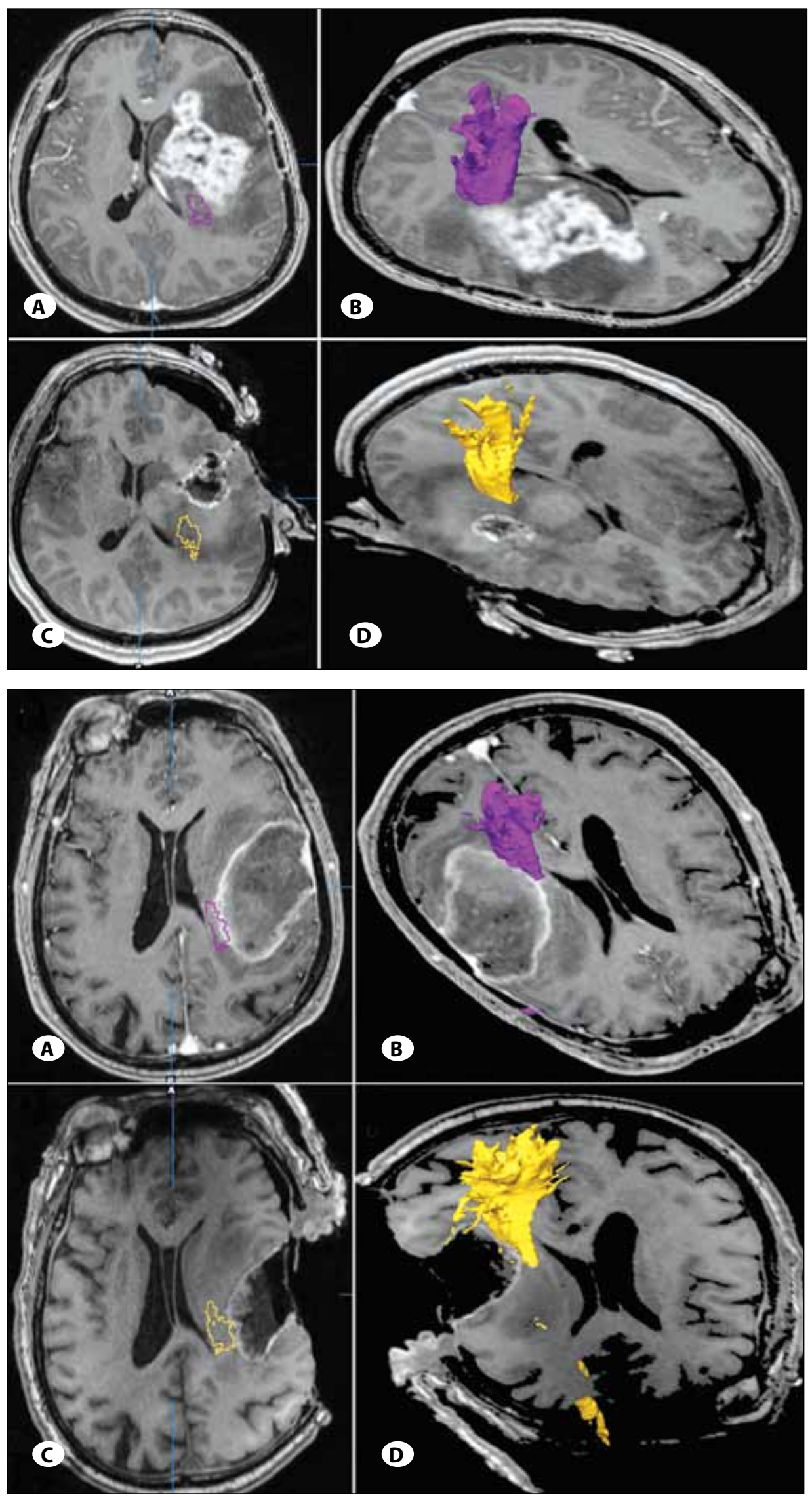

Figure 2: Case No. 2

A) the contour (purple lines) of the preoperative tractogram of pyramidal tract (PT). B) Preoperative 3D tractogram (purple bar) of PT. C) PT left from the resection cavity after tumor removal. Yellow line represents the contour of the intraoperative tractogram of PT. D) Yellow bar represents the intraoperative 3D tractogram.
Figure 3: Case No. 3

A) The contour (purple lines) of preoperative tractogram of pyramidal tract (PT). B) Preoperative 3D tractogram (purple bar) of PT. C) PT was still directly adjacent to resection cavity after tumor removal. Yellow line represents the contour of the intraoperative tractogram of PT. D) Yellow bar represents the intraoperative $3 D$ tractogram. 

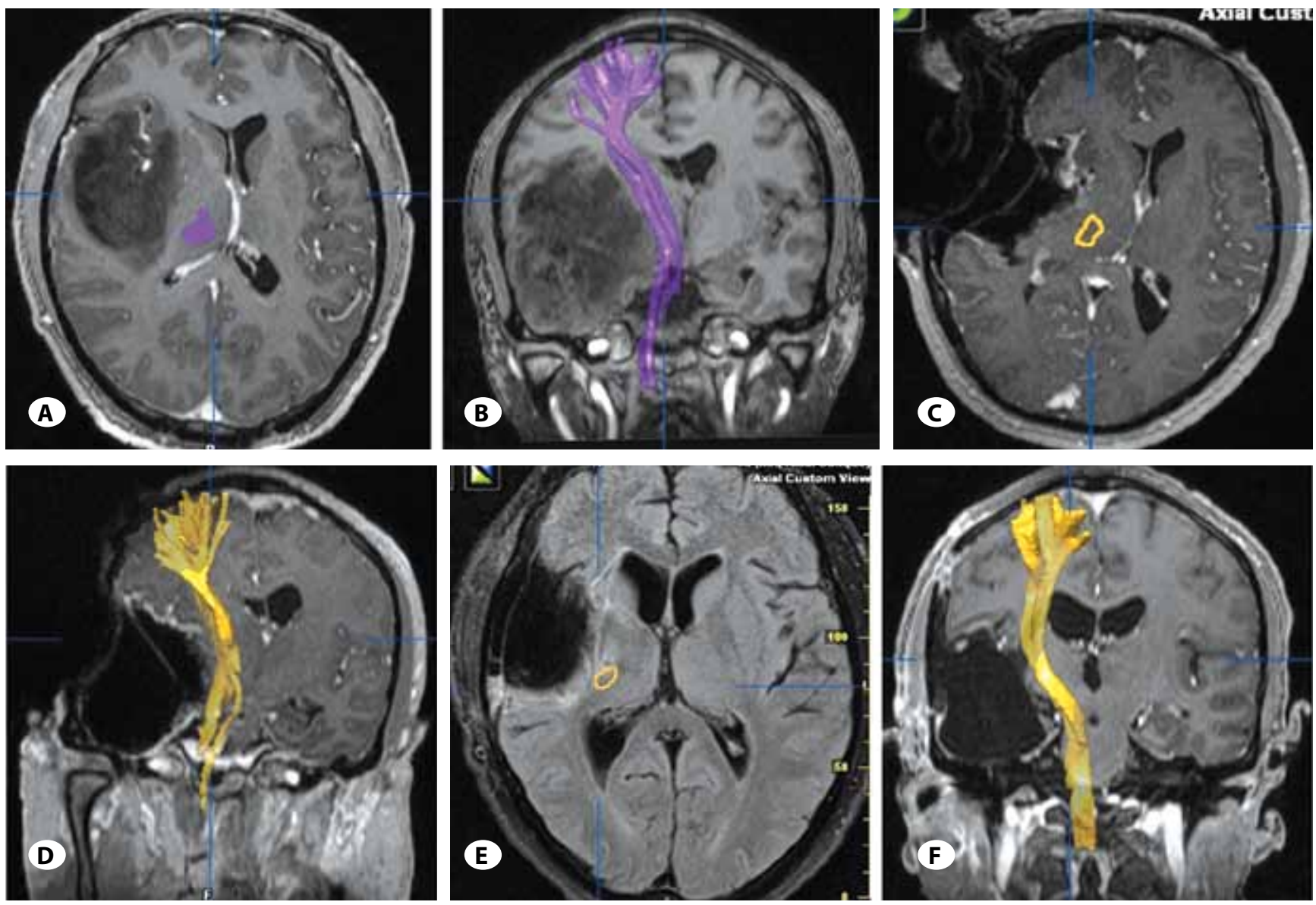

Figure 4: Case No. 4 A, B) Preoperative images. Purple color represents the location of pyramidal tract (PT). C, D) Intraoperative tractogram of PT (yellow color), Tumor had been removed. E, F) images of 6 months; yellow color indicates PT.

way to identify white matter tract, subcortical mapping technique had been used to find the location of PT during glioma surgery for a long time. In the related papers, the reported transient motor deficits were $37 \%$ and dropped to $7 \%$ in long term follow up $(8,20)$. Hence, our data might add up to the evidences which supported the accuracy and helpfulness of locating of the PT by DTI and FT during surgery.

As for intraoperative situation, we found that changes of the distances between PT and glioma were not the same in this group, besides the unpredictable shifting of the PT. In 28 (70\%) patients, the distances between the resection cavities and PT tractogram had increased after surgery, such as illustrative case 1, case 2 and case 4. The distances between PT and resection cavities seemed stable during recovery process, even if the brain tissues shifted to normal position compared with intraoperative images, such as case 1 and case 4 . While in other $12(30 \%)$ patients, intraoperative PT tractogram still adjoined the tumor resection cavities after tumor removal, for example case 3 . We consider the possible reason was that relatively normal brain tissue might locate between PT and the tumors. These brain tissues were displaced or compressed by the tumor before surgery and released after surgery.
We further found that all the 12 patients whose intraoperative PT tractogram still adjoined the tumor resection cavities, had transient aggravated motor deficits after surgery and three of them had persistent aggravated deficits. While in other 28 patient, only 2 had transient aggravated motor deficits. The reason seems obvious. As we all know, surgical procedures can address transient effects to the close surrounding brain tissue, for example thermal effects or coagulation of small bleeding vessels. So, PT might be influenced and leaded to transient aggravated motor deficits, if it was directly adjacent to the edge of tumor resection cavity indeed. In the same reason, it was also likely to be damaged accidentally in this situation, leading to persistent deficits. In this sense, these results might also support the accuracy of PT's location revealed by the DTI based FT and partially explained why the patients with the same relationship between PT and the tumor had different surgical results.

In this group of patients, only 19 patients had mild motor deficits preoperatively, even if the PTs were besides the glioma. We confirmed that PTs were more likely to directly adjacent to the resection cavities after tumor removal in these patients than others without preoperative motor deficits $(57.9 \%$ vs. $4.76 \%)$. This result might indicate that 
patients with preoperative motor deficits might face more risk of postoperative neurological deficits, when their tractogram of PT was directly adjacent to the glioma. Why has this happened? Stadlbauer et al had confirmed that PT in the patients with sensormotor deficits had significantly lower FA and higher mean diffusivity (MD) value than that in the patients without deficits, which indicated that PT was affected more greatly by glioma (18). So, PT was more likely to be infiltrated by the glioma in the patients with preoperative motor deficits, leading to PT bordering the resection cavities. On the other hand, it must be mentioned that our study only involved the patients with their PTs directly adjacent to glioma. Whether or not this result is truth in other situations, such as the tumors are not glioma or PT tractogram is at a distance from the tumor, still need confirmation by further study.

The present study still has some limitations. First, this was not a random controlled study and the sample size was still small. So, the conclusion needs to be confirmed by studies with large sample size and better study design. Second, intraoperative neurophysiologic monitoring technology was not used in this study. Subcortical electrical mapping has been confirmed to be an effective intraoperative neurophysiologic monitoring tool to identify subcortical white matters during surgery. Combination of subcortical electrical mapping together with PT navigation may have better surgical results in glioma surgery $(13,17)$. We began to use these two methods together from 2013. The surgical results are encouraging. The data is being collected and will be reported in another paper. So, in this group of patients who received operations before 2013, we did not use subcortical electrical mapping to confirm the localization of PT during surgery.

\section{CONCLUSION}

DTI based FT is helpful in protection for PT during glioma surgery, even if PT is directly adjacent to the glioma. Patients with preoperative motor deficits face more risk of persistent aggravated deficits after surgery in this situation.

\section{REFERENCES}

1. Basser PJ, Pajevic S, Pierpaoli C, Duda J, Aldroubi A: In vivo fiber tractography using DT-MRI data. Magn Reson Med 44:625-632,2000

2. Bello L, Gambini A, Castellano A, Carrabba G, Acerbi F, Fava E, Giussani C, Cadioli M, Blasi V, Casarotti A, Papagno C, Gupta AK, Gaini S, Scotti G, Falini A: Motor and language DTI fiber tracking combined with intraoperative subcortical mapping for surgical removal of gliomas. Neuroimage 39:369-382,2008

3. Chen X, Weigel D, Ganslandt O, Fahlbusch R, Buchfelder M, Nimsky C: Diffusion tensor-based fiber tracking and intraoperative neuronavigation for the recection of a brainstem cavernous angioma. Surg Neurol 68:285-291,2007

4. Clark CA, Barrick TR, Murphy MM, Bell BA: White matter fiber tracking in patients with space-occupying lesions of the brain: A new technique for neurosurgical planning. Neuroimage 20:1601-1608,2003
5. Coenen VA, Krings T, Mayfrank L, Polin RS, Reinges $M H$, Thron A, Gilsbach JM: Three-dimensional visualization of the pyramidal tract in a neuronavigation system during brain tumor surgery: First experiences and technical note. Neurosurgery 49:86-92,2001

6. Hammerstad JP: Strength and reflexes. In: Goetz CG, (ed), Textbook of Clinical Neurology. 2nd ed. Philadelphia: Elsevier BV Publishers, 2003:225-265

7. Hou $Y Z, C$ hen $X L, X u B N$ : Prediction of the location of the pyramidal tract in patients with thalamic or basal ganglia tumors. PLoS One 7(11):e48585,2012

8. Keles GE, Lundin DA, Lamborn KR, Chang EF, Ojemann G, Berger MS: Intraoperative subcortical stimulation mapping for hemispherical perirolandic gliomas located within or adjacent to the descending motor pathways: Evaluation of morbidity and assessment of functional outcome in 294 patients. J Neurosurg 100:369-375,2004

9. Kinoshita $M$, Yamada $K$, Hashimoto $N$, Kato $A$, Izumoto $\mathrm{S}$, Baba T, Maruno M, Nishimura T, Yoshimine T: Fibertracking does not accurately estimate size of fiber bundle in pathological condition: Initial neurosurgical experience using neuronavigation and subcortical white matter stimulation. Neuroimage 25: 424-442,2005

10. Kunimatsu A, Aoki S, Masutani Y, Abe O, Hayashi N, Mori H, Masumoto T, Ohtomo K: The optimal trackability threshold of fractional anisotropy for diffusion tensor tractography of the corticospinal tract. Magn Reson Med Sci 3:11-17,2004

11. Lawes IN, Barrick TR, Murugam V, Spierings N, Evans DR, Song $M$, Clark CA: Atlas-based segmentation of white matter tracts of the humanbrain using diffusion tensor tractography and comparison with classical dissection. Neurolmage 39:6279,2008

12. Lazar M, Weinstein DM, Tsuruda JS, Hasan KM, Arfanakis K, Meyerand ME, Badie B, Rowley HA, Haughton V, Field A, Alexander AL: White matter tractography using diffusion tensor deflection. Hum Brain Mapp 18:306-321,2003

13. Mikuni N, Okada T, Nishida N, Taki J, Enatsu R, Ikeda A, Miki $\mathrm{Y}$, Hanakawa T, Fukuyama $\mathrm{H}$, Hashimoto $\mathrm{N}$ : Clinical impact of integrated functional neuronavigation and subcortical electrical stimulation to preserve motor function during resection of brain tumors. J Neurosurg 106:593-598,2007

14. Mori S, van Zijl PC: Fiber tracking: Principles and strategies: A technical review. NMR Biomed 15:468-480,2002

15. Nimsky C, Ganslandt O, Hastreiter P, Wang R, Benner T, Sorensen AG, Fahlbusch R: Preoperative and intraoperative diffusion tensor imaging-based fiber tracking in glioma surgery. Neurosurgery 56:130-138,2005

16. Nimsky C, Grummich P, Sorensen AG, Fahlbusch R, Ganslandt $\mathrm{O}$ : Visualization of the pyramidal tract in glioma surgery by integrating diffusion tensor imaging in functional neuronavigation. Zentralbl Neurochir 66:133-141,2007

17. Ozawa N, Muragaki Y, Nakamura R, Iseki H: Identification of the pyramidal tract by neuronavigation based on intraoperative diffusion-weighted imaging combined with subcortical stimulation. Stereotact Funct Neurosurg 87:18-24,2009 
18. Stadlbauer A, Ganslandt O, Buslei R, Hammen T, Gruber S, Moser E, Buchfelder M, Salomonowitz E, Nimsky C: Gliomas: Histopathologic evaluation of changes in directionality and magnitude of water diffusion at diffusion-tensor mri maging. Radiology 240:803-810,2006

19. Stadlbauer A, Nimsky C, Buslei R, Salomonowitz E, Hammen T, Buchfelder M, Moser E, Ernst-Stecken A, Ganslandt O: Diffusion tensor imaging and optimized fiber tracking in glioma patients: Histopathologic evaluation of tumor-invaded white matter structures. Neuroimage 34: 949-956,2007

20. Signorelli F, Ruggeri F, lofrida G, Isnard J, Chirchiglia D, Lavano A, Volpentesta G, Signorelli CD, Guyotat J: Indications and limits of intraoperative cortica-subcortical mapping in brain tumor surgery: An analysis of 101 consecutive cases. J Neurosurg Sci 51:113-127,2007
22. Wakana S, Caprihan A, Panzenboeck MM, Fallon JH, Perry M, Gollub RL, Hua K, Zhang J, Jiang H, Dubey P, Blitz A, van Zijl P, Mori S: Reproducibility of quantitative tractography methods applied to cerebral white matter. Neuroimage 36:630644,2007

21. Wu JS, Zhou LF, Tang WJ, Mao Y, Hu J, Song YY, Hong XN, $\mathrm{Du} \mathrm{GH}$ : Clinical evaluation and follow-up outcome of diffusion tensor imaging-based functional neuronavigation: A prospective, controlled study in patients with gliomas involving pyramidal tracts. Neurosurgery 61:935-949, 2005 